\title{
Prognostic utility of epidermal growth factor receptor (EGFR) expression in prostatic acinar adenocarcinoma
}

\author{
Atif Ali hashmi ${ }^{1 *}$, Shumaila Kanwal Hashmi², Muhammad Irfan' ${ }^{1}$, Huda Asif ${ }^{2}$, Laila Nisar ${ }^{1}$, Maheen Naeem', \\ Erum Yousuf Khan ${ }^{1}$, Samina Baloch ${ }^{1}$ and Naveen Faridi ${ }^{1}$
}

\begin{abstract}
Background: Epidermal growth factor receptor (EGFR) is potential prognostic biomarker expressed in many human cancers. Prognostic significance of EGFR immunohistochemical expression has not been established in prostatic acinar adenocarcinoma, therefore we aimed to evaluate the frequency of expression of EGFR in prostatic adenocarcinoma and its association with other prognostic parameters.

Methods: The study included 123 cases of biopsy proven prostatic acinar adenocarcinoma treated at Liaquat National hospital, Karachi from January 2013 till December 2017. Paraffin blocks of all cases were retrieved; sections were cut and stained with haematoxylin and eosin. Pathologic characteristics including tumor quantification, WHO grade group, gleason score, perineural and lymphovascular invasion were evaluated. EGFR immunohistochemistry (IHC) was performed on all tissue blocks.

Results: Mean age of the patients included in the study was $69.05 \pm 8.68$ years. High gleason scores i.e. 8 \& 9 were noted in 22\% (27 cases) and 22.8\% (28 cases) respectively. Similarly, 22.8\% (28 cases) showed WHO grade group 5. 52.8\% (65 cases) had $>50 \%$ tissue involvement by carcinoma and perineural invasion was seen in $37.4 \%$ (46 cases). Positive EGFR expression was noted in 18.7\% (23 cases), while $81.3 \%$ (100 cases) showed negative EGFR expression. Significant association of EGFR expression was noted with gleason score ( $p$-value $=<0.001)$, WHO grade $(p=<0.001)$, tumor quantification $(p=0.007)$ and perineural invasion $(p=<0.001$ ). Moreover, significant association of EGFR expression was also seen with disease recurrence and Her2neu over expression. Patients with low gleason scores (score 6 and 7$)$ and lower grade group $(1,2$ \& 3) were less likely to have positive EGFR expression as compared to patients with high gleason score (score 9) and higher grade group (5). Similarly, patients with perineural invasion were more likely to have positive EGFR expression.

Conclusion: We found a relatively low EGFR expression in our patients with prostatic adenocarcinoma; however, its association with poor prognostic parameters like high gleason score, higher grade group, perineural invasion, higher tissue involvement by cancer and disease recurrence signifies its importance as a prognostic parameter in prostatic acinar adenocarcinoma.
\end{abstract}

Keywords: Epidermal growth factor receptor, EGFR, Prostatic acinar adenocarcinoma, Gleason score, WHO grade group

\footnotetext{
* Correspondence: doc_atif2005@yahoo.com

${ }^{1}$ Liaquat National Hospital and Medical College, Karachi, Pakistan

Full list of author information is available at the end of the article
}

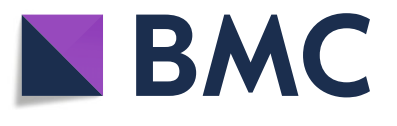

(c) The Author(s). 2019 Open Access This article is distributed under the terms of the Creative Commons Attribution 4.0 International License (http://creativecommons.org/licenses/by/4.0/), which permits unrestricted use, distribution, and reproduction in any medium, provided you give appropriate credit to the original author(s) and the source, provide a link to the Creative Commons license, and indicate if changes were made. The Creative Commons Public Domain Dedication waiver (http://creativecommons.org/publicdomain/zero/1.0/) applies to the data made available in this article, unless otherwise stated. 


\section{Introduction}

Prostatic adenocarcinoma is one of the most common malignancies in males. Age standardized incidence of prostatic cancer in United States is 124.8/10,000. Prevalence of prostatic cancer in age group 61-70 years is $65 \%$, while its $83 \%$ in age group $71-80$ years [1]. The most common histologic subtype of prostatic cancer is acinar adenocarcinoma which arises from prostatic acini. The major prognostic parameters of prostatic acinar adenocarcinoma include gleason score, percentage of tissue involvement by cancer (tumor quantification) and perineural invasion [2, 3]. Epidermal growth factor receptor (EGFR) is a proto-oncogene which is overexpressed in many human cancers and serves as a prognostic biomarker and therapeutic target [4-6]. However, prognostic significance of EGFR immunohistochemical expression (IHC) has not been established in prostatic acinar adenocarcinoma, therefore we aimed to evaluate the frequency of expression of EGFR in prostatic adenocarcinoma and its association with other prognostic parameters.

\section{Methods}

\section{Patients \& methods}

The study included 123 cases of biopsy proven prostatic acinar adenocarcinoma treated at Liaquat National hospital, Karachi. The duration of study was 5 years from January 2013 till December 2017. The approval of the study was taken from research and ethical review committee of Liaquat National Hospital. Informed written consent was taken from all patients that underwent surgery. Paraffin blocks of all cases were retrieved; sections were cut and stained with haematoxylin and eosin. Slides of all cases were reviewed by two senior histopathologists and findings were recorded. Pathologic characteristics including tumor quantification, WHO grade group, gleason score, perineural and lymphovascular invasion were evaluated. Specimens included prostatic chips and radical prostatectomies. Hospital records of all patients were reviewed to determine recurrence and disease free survival. EGFR immunohistochemistry (IHC) was performed on all tissue blocks.

\section{Immunohistochemistry}

DAKO EnVision method was used for EGFR IHC utilizing DAKO Monoclonal Mouse Anti-human Epidermal growth factor Receptor (EGFR), clone H11 according to manufacturers protocol. Both membranous and cytoplasmic staining for EGFR was assessed and recorded. Intensity of staining was scored as follows,

No staining (0),

Weak staining $(1+)$ : weak barely perceptible staining of membranes and weak cytoplasmic staining,

Intermediate staining (2+): Moderate staining of membranes easily appreciable on low power (40X) with moderate cytoplamic staining,

Strong staining (3+): Strong/ dense staining of membranes with moderate to strong cytoplasmic expression.

Percentage of positively stained cells was scored (ranging from 0 to $100 \%$ ).

Moderate to strong staining in more than $10 \%$ cells was considered positive for EGFR expression (Fig. 1). Moreover, intensity score was multiplied with percentage of positively stained cells to calculate and overall IHC score ranging from 0 to 300 .

Her2neu IHC was performed on representative tissue blocks using Polyclonal Rabbit Anti-human c-erbB-2 oncoprotein by DAKO envision method and interpreted according CAP/ASCO guidelines. Membranous reactivity of Her2neu was scored into 0 (negative), 1+ (weak), 2 + (equivocal) and 3+ (strong) according CAP guidelines of reporting Her2neu in breast cancer. 0 and $1+$ staining

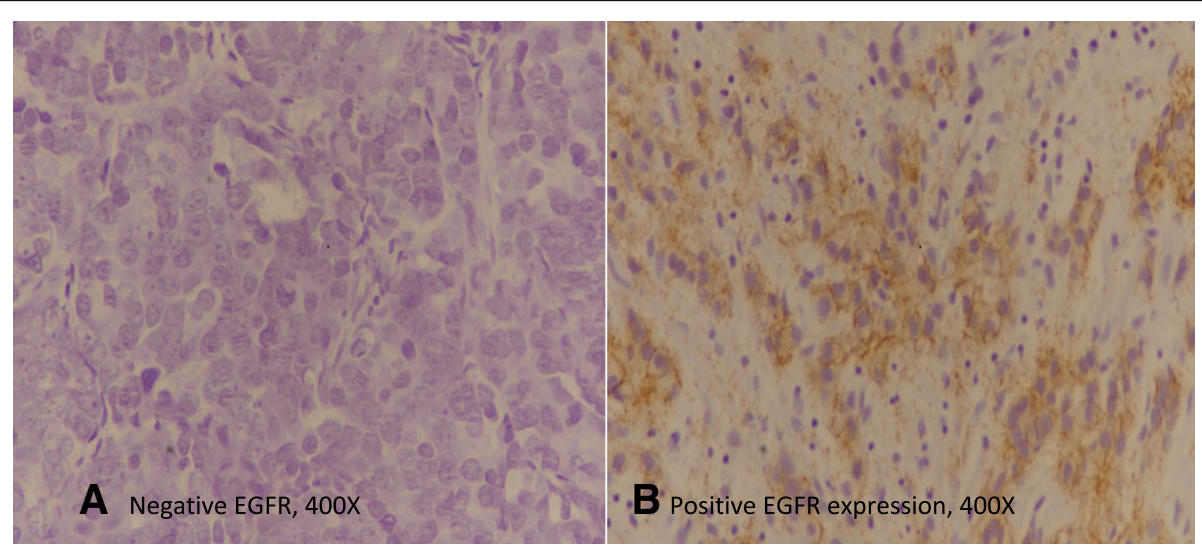

Fig. 1 EGFR expression in prostatic acinar adenocarcinoma, a) Negative EGFR 400X expression, IHC score 0, b) Positive EGFR expression, 400X Intensity score 2+ (moderate), 70\% of tumor cells showing positive EGFR expression, IHC score $=70 \times 2=140$ 
was taken as negative. $3+$ staining were taken as positive. For 2+ (equivocal) cases Fluorescent insitu hybridization (FISH) testing was done using FDA approved Path Vysion Her2 DNA Probe kit and results were interpreted

Table 1 Clinicopathologic characteristics of studied population $(n=123)$

\begin{tabular}{|c|c|c|}
\hline & & $n(\%)$ \\
\hline \multicolumn{3}{|l|}{ Age(years) } \\
\hline \multicolumn{2}{|l|}{ Mean \pm SD } & $69.05 \pm 8.68$ \\
\hline \multicolumn{2}{|l|}{ Mean follow up time (months) } & $21.67 \pm 12.56$ \\
\hline \multicolumn{3}{|l|}{ Age Groups } \\
\hline & $\leq 70$ years & $77(62.6)$ \\
\hline & $>70$ years & $46(37.4)$ \\
\hline \multicolumn{3}{|l|}{ Tumor quantification (\%) } \\
\hline \multicolumn{2}{|l|}{ Mean \pm SD } & $49.83 \pm 30.53$ \\
\hline \multicolumn{3}{|l|}{ Groups } \\
\hline & $<10 \%$ & 23(18.7) \\
\hline & $10-50 \%$ & $35(28.5)$ \\
\hline & $>50 \%$ & $65(52.8)$ \\
\hline \multirow[t]{4}{*}{ Total gleason score } & 6 & 39(31.7) \\
\hline & 7 & 29(23.6) \\
\hline & 8 & $27(22)$ \\
\hline & 9 & 28(22.8) \\
\hline \multirow[t]{5}{*}{ WHO grade group } & Grade 1 & 39(31.7) \\
\hline & Grade 2 & $25(20.3)$ \\
\hline & Grade 3 & $4(3.3)$ \\
\hline & Grade 4 & $27(22)$ \\
\hline & Grade 5 & $28(22.8)$ \\
\hline \multirow[t]{2}{*}{ Perineural invasion } & Present & $46(37.4)$ \\
\hline & Absent & $77(62.6)$ \\
\hline \multirow[t]{2}{*}{ Lymphovascular invasion } & Present & $3(2.4)$ \\
\hline & Absent & $120(97.6)$ \\
\hline \multirow[t]{2}{*}{ Extraprostatic extension } & Present & $7(5.7)$ \\
\hline & Absent & 116(94.3) \\
\hline \multirow[t]{2}{*}{ Seminal vesicle invasion } & Present & $4(3.3)$ \\
\hline & Absent & 119(96.7) \\
\hline \multirow[t]{2}{*}{ Specimen type } & Radical prostatectomy & 18(14.6) \\
\hline & TURP & 105(85.4) \\
\hline \multicolumn{2}{|l|}{ Recurrence duration (months) } & $9.39 \pm 3.22$ \\
\hline \multirow[t]{2}{*}{ Recurrence } & Yes & $33(26.8)$ \\
\hline & No & $90(73.2)$ \\
\hline \multirow[t]{2}{*}{ EFGR expression } & Positive & 23(18.7) \\
\hline & Negative & $100(81.3)$ \\
\hline \multirow[t]{2}{*}{ Her2 neu } & Positive & 28(22.8) \\
\hline & Negative & $95(77.2)$ \\
\hline
\end{tabular}

according to CAP guidelines. Results were recorded as negative (not amplified) or positive (amplified) according to $\mathrm{ASCO} / \mathrm{CAP}$ recommendations [7].

\section{Statistical analysis}

We used statistical package for social sciences (SPSS 21) for data compilation and analysis. For quantitative variables we calculated mean and standard deviation, while frequency and percentage were assessed for qualitative variables. Independent $\mathrm{t}$-test and ANOVA were used to compare mean difference. Chi square test and Fisher exact test was applied to determine association. Odds ratios were calculated by univariate binary logistic regression for significant variables. Survival curves were plotted using Kaplan-Meier method. $P$-value of $\leq 0.05$ was taken as significant.

Table 2 Association of EGFR expression with clinicopathologic parameters in prostatic acinar adenocarcinoma

\begin{tabular}{|c|c|c|c|c|}
\hline & & \multicolumn{2}{|l|}{$n(\%)$} & \multirow{2}{*}{$\begin{array}{l}P- \\
\text { Value }\end{array}$} \\
\hline & & $\begin{array}{l}\text { Positive } \\
(n=23)\end{array}$ & $\begin{array}{l}\text { Negative } \\
(n=100)\end{array}$ & \\
\hline \multirow[t]{2}{*}{ Age Groups } & $\leq 70$ years & $14(60.9)$ & $63(63)$ & \multirow[t]{2}{*}{0.849} \\
\hline & $>70$ years & $9(39.1)$ & $37(37)$ & \\
\hline \multirow[t]{4}{*}{ Total gleason score } & 6 & $1(4.3)$ & $38(38)$ & \multirow[t]{4}{*}{$<0.001$} \\
\hline & 7 & $3(13)$ & $26(26)$ & \\
\hline & 8 & $5(21.7)$ & $22(22)$ & \\
\hline & 9 & $14(60.9)$ & $14(14)$ & \\
\hline \multirow[t]{5}{*}{ WHO grade groupa } & Grade 1 & $1(4.3)$ & $38(38)$ & \multirow[t]{5}{*}{$<0.001$} \\
\hline & Grade 2 & $2(8.7)$ & $23(23)$ & \\
\hline & Grade 3 & $1(4.3)$ & $3(3)$ & \\
\hline & Grade 4 & $5(21.7)$ & $22(22)$ & \\
\hline & Grade 5 & 14(60.9) & $14(14)$ & \\
\hline \multirow[t]{3}{*}{ Tumor Quantificationa } & $<10 \%$ & $1(4.3)$ & $22(22)$ & \multirow[t]{3}{*}{0.007} \\
\hline & $10-50 \%$ & $3(13)$ & $32(32)$ & \\
\hline & $>50 \%$ & 19(82.6) & $46(46)$ & \\
\hline \multirow[t]{2}{*}{ Perineural invasion } & Present & 16(69.6) & $30(30)$ & \multirow[t]{2}{*}{$<0.001$} \\
\hline & Absent & $7(30.4)$ & $70(70)$ & \\
\hline \multirow[t]{2}{*}{ Lymphovascular invasiona } & Present & $0(0)$ & $3(3)$ & \multirow[t]{2}{*}{1.000} \\
\hline & Absent & $23(100)$ & 97(97) & \\
\hline \multirow[t]{2}{*}{ Extraprostatic extensiona } & Present & $0(0)$ & $7(7)$ & \multirow[t]{2}{*}{0.346} \\
\hline & Absent & $23(100)$ & 93(93) & \\
\hline \multirow[t]{2}{*}{ Seminal vesicle invasion a } & Present & $2(8.7)$ & $2(2)$ & \multirow[t]{2}{*}{0.158} \\
\hline & Absent & 21(91.3) & 98(98) & \\
\hline \multirow[t]{2}{*}{ Recurrence } & Yes & 19(82.6) & $14(14)$ & \multirow[t]{2}{*}{$<0.001$} \\
\hline & No & $4(17.4)$ & $86(86)$ & \\
\hline
\end{tabular}

Chi square test was applied

aFisher exact test applied

$P$-Value $\leq 0.05$, considered as significant 


\section{Results}

Mean age of the patients included in the study was $69.05 \pm 8.68$ years. Mean follow up time was $21.67 \pm 12.56$ months. High gleason scores i.e. 8 \& 9 were noted in $22 \%$ ( 27 cases) and $22.8 \%$ ( 28 cases) respectively. Similarly, $22.8 \%$ (28 cases) showed WHO grade group 5. 52.8\% (65 cases) had $>50 \%$ tissue involvement by carcinoma and perineural invasion was seen in $37.4 \%$ (46 cases). $14.6 \%$ (18 cases) were those of radical prostatectomy specimens while $85.4 \%$ (105 cases) while transuretheral resections (TURP). Recurrence of the disease was noted in $26.8 \%$ cases. Her2neu expression was noted in $28.2 \%$ cases. Patient characteristics are shown in Table 1.

\section{EGFR expression in prostatic carcinoma}

Positive EGFR expression was noted in 18.7\% (23 cases), while $81.3 \%$ (100 cases) showed negative EGFR expression. Significant association of EGFR expression was noted with gleason score ( $p$-value $=<0.001)$, WHO grade $(p=<0.001)$, tumor quantification $(p=0.007)$, perineural invasion $(p=<0.001)$ and disease recurrence $(p=<0.001)$ as shown in Table 2.

Patients with low gleason scores (score 6 and 7) and lower grade group $(1,2 \& 3)$ were less likely to have positive EGFR expression as compared to patients with high gleason score (score 9) and higher grade group (5). Similarly, patients with perineural invasion and disease recurrence were more likely to have positive EGFR expression (Table 3).

Table 3 Odds ratio for patients with positive EGFR expression

\begin{tabular}{|c|c|c|c|}
\hline & & odds ratio $(95 \% \mathrm{Cl})$ & $P$-Value \\
\hline \multirow[t]{4}{*}{ Total gleason score } & 6 & $0.026(0.003-0.219)$ & 0.001 \\
\hline & 7 & $0.115(0.028-0.471)$ & 0.003 \\
\hline & 8 & $0.227(0.067-0.771)$ & 0.017 \\
\hline & $9^{\oplus}$ & 1 & \\
\hline \multirow[t]{5}{*}{ WHO grade group } & Grade-1 & $0.026(0.003-0.219)$ & 0.001 \\
\hline & Grade-2 & $0.087(0.017-0.441)$ & 0.003 \\
\hline & Grade-3 & $0.333(0.031-3.606)$ & 0.333 \\
\hline & Grade-5 & $0.227(0.067-0.771)$ & 0.017 \\
\hline & Grade- $5^{\oplus}$ & 1 & 0.001 \\
\hline \multirow[t]{3}{*}{ Tumor Quantification } & $<10 \%$ & $0.110(0.014-0.876)$ & 0.037 \\
\hline & $10-50 \%$ & $0.227(0.062-0.832)$ & 0.025 \\
\hline & $>50 \%$ & 1 & \\
\hline \multirow[t]{2}{*}{ Perineural invasion } & Present & $5.333(1.990-14.293)$ & 0.001 \\
\hline & Absent $^{\oplus}$ & 1 & \\
\hline \multirow[t]{2}{*}{ Recurrence } & Yes & 29.17(8.63-98.55) & $<0.001$ \\
\hline & $\mathrm{No}^{\oplus}$ & 1 & \\
\hline
\end{tabular}

Univariate binary logistic regression was applied ${ }^{\circledR}$ Reference Category
Table 4 shows comparison of mean IHC scores with various clinicopathological parameters and reveals significantly increased IHC scores in cases with gleason score 9 / grade group 5 and cases showing perineural invasion.

Similar to EGFR, Her2neu expression also showed significant association with poor prognostic factors like tumor grade, tumor quantification and disease recurrence. Moreover, Her2neu expression was also found to be associated with EGFR expression as shown in Table 5.

Significant association of both EGFR and Her2neu expression was seen with disease free survival (Figs. 2 and 3).

\section{Discussion}

In the present study, we found an overall low EGFR expression in prostatic acinar adenocarcinoma in our patient population i.e. $18.7 \%$. On the other hand, significant association of EGFR overexpression was noted with poor prognostic parameters like higher

Table 4 Comparison of mean EGFR IHC scores with clinicopathologic parameters

\begin{tabular}{|c|c|c|c|}
\hline & & mean $\pm S D$ & $P$-value \\
\hline Overall & & $6.80 \pm 27.96$ & \\
\hline \multirow[t]{2}{*}{ Age Groups } & $\leq 70$ years & $9.40 \pm 34.94$ & 0.090 \\
\hline & $>70$ years & $2.45 \pm 5.10$ & \\
\hline \multirow[t]{4}{*}{ Total gleason score ${ }^{a}$} & 6 & $0.25 \pm 1.60$ & 0.001 \\
\hline & 7 & $1.55 \pm 4.64$ & \\
\hline & 8 & $3.11 \pm 5.46$ & \\
\hline & 9 & $24.92 \pm 55.06$ & \\
\hline \multirow[t]{5}{*}{ WHO grade groupa } & Grade 1 & $0.25 \pm 1.60$ & 0.003 \\
\hline & Grade 2 & $1.20 \pm 4.15$ & \\
\hline & Grade 3 & $3.75 \pm 7.50$ & \\
\hline & Grade 4 & $3.11 \pm 5.46$ & \\
\hline & Grade 5 & $24.92 \pm 55.06$ & \\
\hline \multirow[t]{3}{*}{ Tumor Quantificationa } & $<10 \%$ & $0.52 \pm 2.50$ & 0.091 \\
\hline & $10-50 \%$ & $1.28 \pm 4.26$ & \\
\hline & $>50 \%$ & $12.00 \pm 37.39$ & \\
\hline \multirow[t]{2}{*}{ Perineural invasion } & Present & $5.28 \pm 6.77$ & 0.643 \\
\hline & Absent & $7.71 \pm 35.01$ & \\
\hline \multirow[t]{2}{*}{ Lymphovascular invasion } & Present & $5.00 \pm 0.00$ & 0.910 \\
\hline & Absent & $6.85 \pm 28.31$ & \\
\hline \multirow[t]{2}{*}{ Extraprostatic extension } & Present & $0.00 \pm 0.00$ & 0.510 \\
\hline & Absent & $7.21 \pm 28.74$ & \\
\hline \multirow[t]{2}{*}{ Seminal vesicle invasion } & Present & $6.00 \pm 6.92$ & 0.954 \\
\hline & Absent & $6.83 \pm 28.41$ & \\
\hline
\end{tabular}

Independent t test was applied.

aANOVA was applied

$P \leq 0.05$, considered as significant 
Table 5 Association of Her2 neu expression with clinicopathologic parameters in prostatic acinar adenocarcinoma

\begin{tabular}{|c|c|c|c|c|}
\hline & & \multicolumn{2}{|l|}{$n(\%)$} & \multirow[t]{2}{*}{$P$-Value } \\
\hline & & $\begin{array}{l}\text { Positive } \\
(n=28)\end{array}$ & $\begin{array}{l}\text { Negative } \\
(n=95)\end{array}$ & \\
\hline \multirow[t]{2}{*}{ Age Group } & $\leq 70$ years & $16(57.1)$ & $61(64.2)$ & \multirow[t]{2}{*}{0.497} \\
\hline & $>70$ years & $12(42.9)$ & $34(35.8)$ & \\
\hline \multirow[t]{4}{*}{ Total gleason score } & 6 & $4(14.3)$ & $35(36.8)$ & \multirow[t]{4}{*}{0.029} \\
\hline & 7 & $5(17.9)$ & $24(25.3)$ & \\
\hline & 8 & $8(28.6)$ & $19(20)$ & \\
\hline & 9 & $11(39.3)$ & $17(17.9)$ & \\
\hline \multirow[t]{5}{*}{ WHO grade group } & Grade 1 & $4(14.3)$ & $35(36.8)$ & \multirow[t]{5}{*}{0.014} \\
\hline & Grade 2 & $3(10.7)$ & $22(23.2)$ & \\
\hline & Grade 3 & $2(7.1)$ & $2(2.1)$ & \\
\hline & Grade 4 & $8(28.6)$ & $19(20)$ & \\
\hline & Grade 5 & $11(39.3)$ & 17(17.9) & \\
\hline \multirow[t]{3}{*}{ Tumor Quantification } & $<10 \%$ & $3(10.7)$ & $20(21.1)$ & \multirow[t]{3}{*}{0.028} \\
\hline & $10-50 \%$ & $4(14.3)$ & $31(32.6)$ & \\
\hline & $>50 \%$ & $21(75)$ & $44(46.3)$ & \\
\hline \multirow[t]{2}{*}{ Perineural invasion } & Present & $14(50)$ & $32(33.7)$ & \multirow[t]{2}{*}{0.117} \\
\hline & Absent & $14(50)$ & 63(66.3) & \\
\hline \multirow[t]{2}{*}{ Lymphovascular invasiona } & Present & $0(0)$ & $3(3.2)$ & \multirow[t]{2}{*}{1.000} \\
\hline & Absent & $28(100)$ & $92(96.8)$ & \\
\hline \multirow[t]{2}{*}{ Extraprostatic extensiona } & Present & $0(0)$ & $7(7.4)$ & \multirow[t]{2}{*}{0.349} \\
\hline & Absent & $28(100)$ & $88(92.6)$ & \\
\hline \multirow[t]{2}{*}{ Seminal vesicle invasion a } & Present & $2(7.1)$ & $2(2.1)$ & \multirow[t]{2}{*}{0.222} \\
\hline & Absent & 26(92.9) & 93(97.9) & \\
\hline \multirow[t]{2}{*}{ Recurrence } & Yes & $19(67.9)$ & $14(14.7)$ & \multirow[t]{2}{*}{$<0.001$} \\
\hline & No & $9(32.1)$ & $81(85.3)$ & \\
\hline \multirow[t]{2}{*}{ EGFR } & Positive & $8(28.6)$ & $92(96.8)$ & \multirow[t]{2}{*}{$<0.001$} \\
\hline & Negative & 20(71.4) & $3(3.2)$ & \\
\hline
\end{tabular}

Chi square test was applied

aFisher exact test applied

P-Value $\leq 0.05$, considered as significant

gleason score, perineural invasion and higher tissue involvement by carcinoma which are major prognostic factors in prostatic carcinoma. Moreover, significant association of EGFR expression was noted with disease recurrence and Her2neu expression. To our knowledge, this is the first study evaluating EGFR expression in prostatic carcinoma in Pakistani patients and overall data regarding EGFR expression in prostatic carcinoma is limited connoting the importance of the present study.

Evaluation of EGFR overexpression in prostatic carcinoma and its role as prognostic biomarker has been evaluated in previous studies [8-11]. Lorenzo GD et al., found EGFR expression in 41.4 and $75.9 \%$ of non-metastatic prostatic carcinoma treated with radical prostatectomy and hormonal therapy followed by radical prostatectomy respectively. They found EGFR expression to be associated with high gleason score, high serum PSA and higher frequency of disease relapse and progression to androgen independence, thus proving an immense prognostic significance of EGFR expression in prostatic carcinoma [12]. Similarly, in another study EGFR was significantly correlated with high serum PSA levels, extraprostatic extension, seminal vesicle invasion and disease recurrence [13]. On the other hand, Back $\mathrm{KH}$ et al., found $40.9 \%$ EGFR expression in prostatic carcinoma and they didn't find any significant association of EGFR expression with other clinicopathologic parameters except its inverse correlation with androgen receptor expression [14]. In contrast to these studies, we 


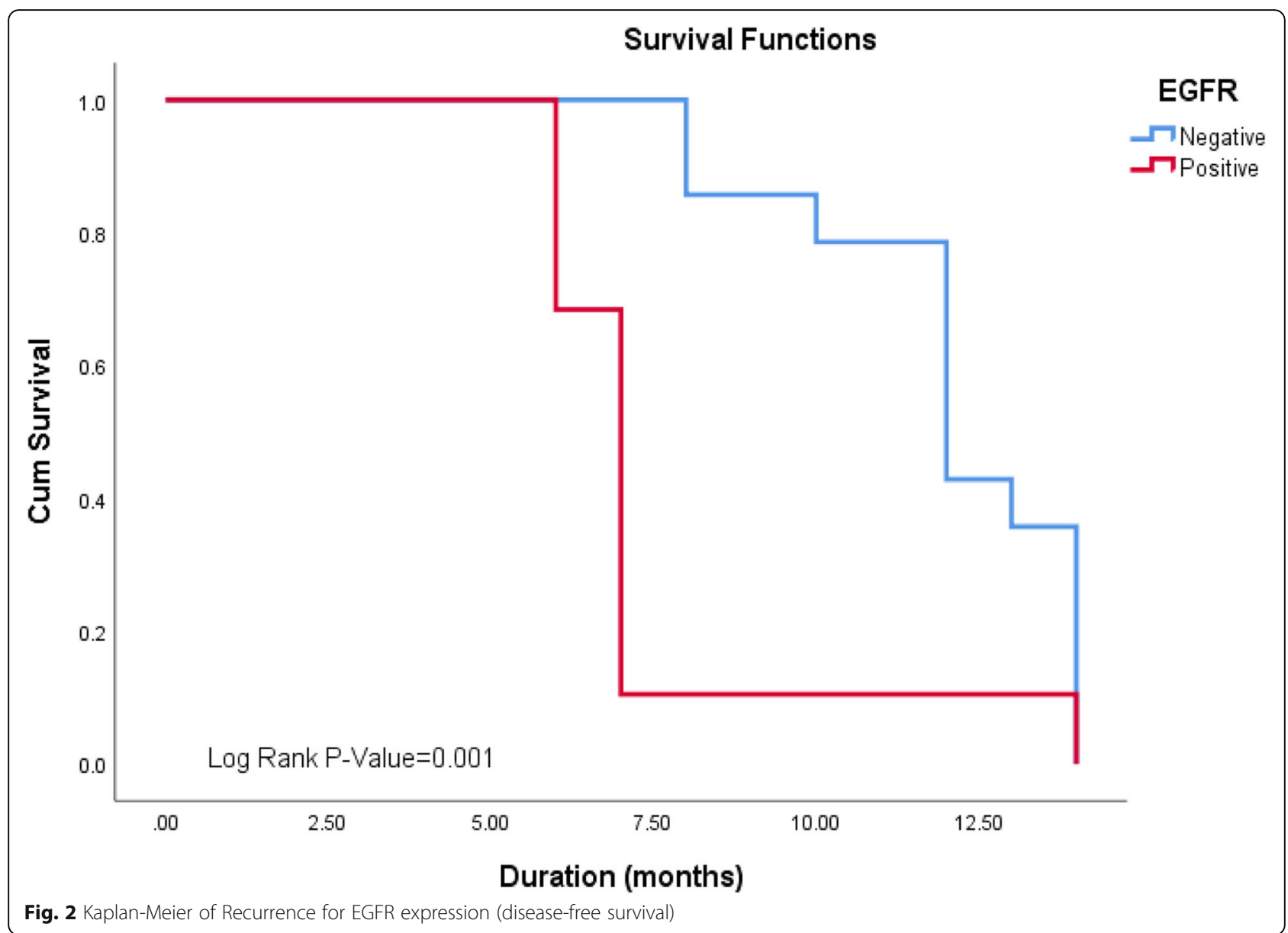

found a relatively low EGFR expression in our patients with prostatic adenocarcinoma; however, its association with gleason score, perineural invasion and higher tissue involvement signifies its importance as a prognostic biomarker in prostatic carcinoma. Moreover, we found a significant association of EGFR expression with worse disease free survival and recurrence.

The major limitation of the study was that we did not perform molecular studies to establish an association of positive IHC expression with molecular abnormalities and gene amplifications. Identification of underlying gene amplification may also help in identifying patients that can benefit from anti-EGFR therapy. Despite these limitations, the results of our study signify the prognostic utility of EGFR expression in prostatic acinar adenocarcinoma.

The overall expression of EGFR in prostatic carcinoma found in our study was low as explained earlier compared to the international data. This may be due to different cancer characteristics and underlying gene mutations in our population. Another explanation for this discordance may be difference in IHC interpretation in different studies. As many authors, didn't incorporated the intensity of EGFR expression to evaluate IHC score and different cut offs were taken to define positive EGFR expression. Therefore, we suggest that IHC scores should be correlated with gene amplification to define a standard cut-off for positive EGFR IHC expression. On the other hand, the role of EGFR as a prognostic biomarker can't be underestimated as we found a strong association of EGFR expression with prognostic parameters supported by international data.

Although, overall expression of EGFR in prostatic adenocarcinoma was low in our study, but its association with high grade and poor prognostic features signifies its importance in those patients not being benefited by conventional therapeutic regimens. Earlier studies also revealed association of EGFR expression with androgen receptor independence nullifying the role of anti-androgen therapy in these patients. Clinical trials involving the use of specific therapies are complex in design and require restricted ethical care $[15,16]$. Therefore, role of these new therapeutic options like anti-EGFR therapy should be evaluated in patients with 


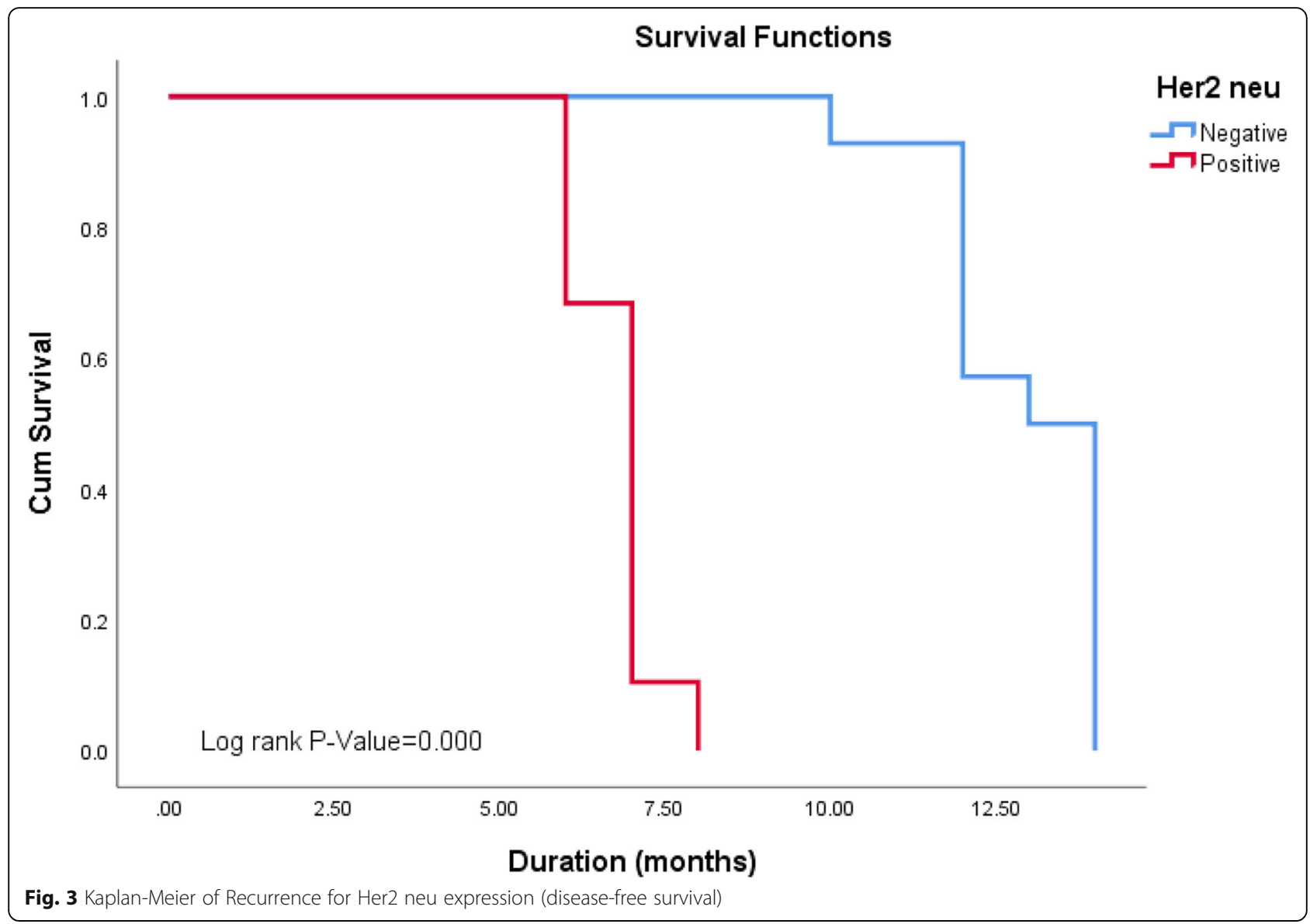

prostatic carcinomas of high histological grades (Gleason and $\mathrm{WHO}$ ) that are outside the current therapeutic possibilities.

\section{Conclusion}

We found a relatively low EGFR expression in our patients with prostatic adenocarcinoma; however, its association with poor prognostic parameters likes high gleason score, higher grade group, perineural invasion, higher tissue involvement by cancer and poor disease free survival signifies its importance as a prognostic parameter in prostatic acinar adenocarcinoma.

\section{Abbreviations}

EGFR: Epidermal growth factor receptor; IHC: Immunohistochemistry

\section{Acknowledgments}

We gratefully acknowledge all staff members of Pathology, Liaquat National Hospital, Karachi, Pakistan for their help and cooperation.

\section{Funding}

No Funding was provided.

Availability of data and materials

Please contact first author (Atif Ali Hashmi) for data requests.

\section{Authors' contributions}

$\mathrm{AAH}, \mathrm{SKH}$ and Ml: main author of manuscript, have made substantial contributions to conception and design of study. HA, LN, MN, EYK, SB and NF: been involved in drafting the manuscript, revising it critically for important intellectual content. HA, LN, MN, EYK, SB and NF: have been involved in analysis of the data and gave final approval and revision of the manuscript. All authors read and approved the final manuscript.

\section{Ethics approval and consent to participate}

Ethics committee of Liaquat National Hospital, Karachi, Pakistan approved the study. Written informed consent was obtained from the patients for the participation.

\section{Consent for publication}

All authors agreed to publish.

Competing interests

The authors declare that they have no competing interests.

\section{Publisher's Note}

Springer Nature remains neutral with regard to jurisdictional claims in published maps and institutional affiliations.

\section{Author details}

${ }^{1}$ Liaquat National Hospital and Medical College, Karachi, Pakistan. ${ }^{2} \mathrm{CMH}$ institute of medical sciences, Multan, Pakistan. 
Received: 28 September 2018 Accepted: 26 November 2018

Published online: 10 January 2019

\section{References}

1. Haas GP, Delongchamps N, Brawley OW, Wang CY, de la Roza G. The worldwide epidemiology of prostate cancer: perspectives from autopsy studies. Can J Urol. 2008;15(1):3866-71.

2. Epstein Jl, Amin MB, Reuter VE, Humphrey PA. Contemporary Gleason Grading of Prostatic Carcinoma: An Update With Discussion on Practical Issues to Implement the 2014 International Society of Urological Pathology (ISUP) Consensus Conference on Gleason Grading of Prostatic Carcinoma. Am J Surg Pathol. 2017;41(4):e1-7.

3. Kishan AU, Shaikh T, Wang PC, Reiter RE, Said J, Raghavan G, Nickols NG, Aronson WJ, Sadeghi A, Kamrava M, Demanes DJ, Steinberg ML, Horwitz EM, Kupelian PA, King CR. Clinical Outcomes for Patients with Gleason Score 9-10 Prostate Adenocarcinoma Treated With Radiotherapy or Radical Prostatectomy: A Multi-institutional Comparative Analysis. Eur Urol. 2017; 71(5):766-73.

4. Wells A. Molecules in focus: EGFR receptor. Int J Biochem Cell Biol. 1999;31:637-43.

5. Hashmi AA, Hussain ZF, Aijaz S, Irfan M, Khan EY, Naz S, Faridi N, Khan A, Edhi MM. Immunohistochemical expression of epidermal growth factor receptor (EGFR) in South Asian head and neck squamous cell carcinoma: association with various risk factors and clinico-pathologic and prognostic parameters. World J Surg Oncol. 2018;16(1):118.

6. Hashmi AA, Hussain ZF, Irfan M, Khan EY, Faridi N, Naqvi H, Khan A, Edhi MM. Prognostic significance of epidermal growth factor receptor (EGFR) over expression in urothelial carcinoma of urinary bladder. BMC Urol. 2018; 18(1):59.

7. Wolff AC, Hammond ME, Hicks DG, et al. Recommendations for human epidermal growth factor receptor 2 testing in breast cancer: American Society of Clinical Oncology - College of American Pathologists (ASCO/CAP) Clinical Practice Guideline Update (2013). Arch Pathol Lab Med. 2014;138(2): 241-56.

8. Fox SB, Persad RA, Coleman N, Day CA, Silcocks PB, Collins CC. Prognostic value of c-erbB-2 and epidermal growth factor receptor in stage A1 (T1a) prostatic adenocarcinoma. Br J Urol. 1994;74:214-20.

9. Calvo BF, Levine AM, Marcos M, Collins QF, lacocca MV, Caskey LS, et al. Human epidermal receptor-2 expression in prostate cancer. Clin Cancer Res. 2003;9:1087-97.

10. Cai C, Portnoy DC, Wang H, Jiang X, Chen S, Balk SP. Androgen receptor expression in prostate cancer cells is suppressed by activation of epidermal growth factor receptor and ErbB2. Cancer Res. 2009;69:5202-9.

11. Schlomm T, Kirstein P, Iwers L, Daniel B, Steuber T, Walz J, et al. Clinical significance of epidermal growth factor receptor protein overexpression and gene copy number gains in prostate cancer. Clin Cancer Res. 2007; 13(22 Pt 1):6579-84.

12. Di Lorenzo G, Tortora G, D'Armiento FP, De Rosa G, Staibano S, Autorino R, D'Armiento M, De Laurentiis M, De Placido S, Catalano G, Bianco AR, Ciardiello F. Expression of epidermal growth factor receptor correlates with disease relapse and progression to androgen-independence in human prostate cancer. Clin Cancer Res. 2002;8(11):3438-44.

13. Lee JW, Cho KS, Han KS, Kim EK, Joung JY, Seo HK, et al. Epidermal growth factor receptor as predicting factor on biochemical recurrence after radical prostatectomy: a prospective study. Korean J Urol. 2008;49:974-80.

14. Baek KH, Hong ME, Jung YY, Lee CH, Lee TJ, Park ES, Kim MK, Yoo JH, Lee SW. Correlation of AR, EGFR, and HER2 Expression Levels in Prostate Cancer: Immunohistochemical Analysis and Chromogenic In Situ Hybridization. Cancer Res Treat. 2012;44(1):50-6

15. Baciarello G, Gizzi M, Fizazi K. Advancing therapies in metastatic castrationresistant prostate cancer. Expert Opin Pharmacother. 2018;19(16):1797-804.

16. Giacinti S, Poti G, Roberto M, Macrini S, Bassanelli M, DI Pietro F, Aschelter AM, Ceribelli A, Ruggeri EM, Marchetti P. Molecular Basis of Drug Resistance and Insights for New Treatment Approaches in MCRPC. Anticancer Res. 2018:38(11):6029-39.

Ready to submit your research? Choose BMC and benefit from:

- fast, convenient online submission

- thorough peer review by experienced researchers in your field

- rapid publication on acceptance

- support for research data, including large and complex data types

- gold Open Access which fosters wider collaboration and increased citations

- maximum visibility for your research: over $100 \mathrm{M}$ website views per year

At $\mathrm{BMC}$, research is always in progress.

Learn more biomedcentral.com/submissions 